Arch. Vet. Scienc. 4(1), 99-102, 1999

Printed in Brazil

\title{
CARBOHYDRATE METABOLISM IN FISH ERYTHROCYTES: BLOOD GLUCOSE COMPARTMENTALIZATION*
}

\author{
EDSON RODRIGUES $^{1 * *}$; ALMELISA MEDEIROS ${ }^{2}$, RUBENS ROSA $^{3}$ METRY BACILA $^{2}$
}

Brazilian Antarctic Station Commander Ferraz, King George Island, South Shetlands. ${ }^{1}$ Faculdade de Ciências Farmacêuticas, Universidade São Francisco, Bragança Paulista, SP, Brazil. ${ }^{2}$ Laboratório de Piscicultura, Universidade Federal do Paraná, Curitiba PR, Brazil. ${ }^{3}$ Centro de Ciências Biológicas e da Saúde, Pontifícia Universidade Católica do Paraná - PUC-PR, Curitiba, Paraná, Brasil.

\begin{abstract}
With the aim to study the problem of erythrocyte glucose permeation and blood compartmentalization in fish, a comparative study has been carried out on blood parameters from fish adapted to different aquatic environments: Antarctic seas, marine subtropical seas and continental tropical waters. One Antarctic fish, Notothenia neglecta, four marine subtropical fish species, Menticirrhus litoralis, Rhinobatus percellens, Netuma barba and Mugil spp, and two tropical fish species, Prochilodus scropha and Piaractus mesopotamicus, were de fish studied. Values for hematocrite, hemoglobin and plasma and whole blood glucose were assayed.
\end{abstract}

RESUMO - Foi levado a efeito um estudo sobre a permeação eritrocitária da glicose e sua compartimentalização sangüínea em peixes. Para tanto fez-se um estudo comparativo de parâmetros sangüíneos de peixes adaptados a diferentes ambientes aquáticos: mares antárticos, mares subtropicais e águas continentais tropicais. Para tanto foi estudado um peixe antártico, Notothenia neglecta, duas espécies de peixes marinhos subtropicais, Rhinobatus percellen e Netuma barba e duas espécies de peixes de águas tropicais continentais, Prochilodus scropha e Piaractus mesopotamicus. Foram estabelecidos, também, os valores para hematócrito, hemoglobina e para glicose plasmática e do sangue total das espécies estudadas.

\section{Introduction}

Levels of glucose blood plasma in fish has been the subject of several papers from different laboratories. Factors as the effect of temperature, the permeability of glucose by the erythrocyte membrane, the relationship between the alarm reaction caused by stress and glucose metabolism, among others, have been considered in regard to this topic of the fish biochemical and physiological behavior (FLETCHER, 1984; TIIHONEN and NIKIMAA,1991). OTTOLENGHI et al. (1995), for instance, showed that catfish Ictalurus melas and Ictalurus punctatus, acclimated to temperatures between $24^{\circ} \mathrm{C}$ and $36^{\circ} \mathrm{C}$ display lower levels of blood glucose at the higher temperatures. Both in the control and in acclimated fish, the blood glucose peak was reached after 1 minute, beginning to decrease after 5 minutes being drastically reduced after 4 hours and reaching the starting level after 24 hours. TIIHONEN and NIKIMAA (1991), studying the D-glucose permeability in river lamprey (Lampetra fluviatilis) and carp (Cyprinus carpio) erythrocytes by means of the blood transport of 3-O-methyl-D-glucose, concluded that for most teleost fish so far studied, low

\footnotetext{
*With a grant-in-aid from the Brazilian Antarctic Program (Brazilian Antarctic Program, Laboratório de Piscicultura, Universidade Federal do Paraná, Curitiba, PR, Brasil) PROANTAR-CNPq. ** To whom all correspondence should be sent: Prof. Edson Rodrigues - Universidade São Francisco, Faculdade de Ciências Farmacêuticas, Av. São Francisco de Assis, 218, Bragança Paulista, SP, Brazil, CEP 12.900-00.
}

glucose permeability is insufficient to maintain normal energy metabolism in carp erythrocytes while in agnathans facilitated glucose transport seems to be quite efficient. A very important issue in this type of research with fish has been the fact that those animals undergo stress alarm reactions, implying this way that all the handling of the fish for the purpose of obtaining samples of blood by vein puncture are subjected to give false results. However, according to KRIEGER-AZZOLINI et al. (1989) the basal glycemia and plasma cortisol levels assayed suggested that no evidence of stress was demonstrated during the initial 3-5 minutes of the handling of the fish. By assaying postoperative levels of plasma glucose in Limanda individuals cannulated 4 hours after a satiation meal, FLETCHER (1984) found out that almost no variation in the levels of plasma glucose from 5 to 145 hours postoperative, the plasma glucose levels tending to fluctuate for a short time after cannulation before steadying some 48 hours after the operation. The problem of the acute handling stress underwent by the brown trout, Salmo trutta, was studied by PICKERING et al. (1982). It has been demonstrated that plasma glucose concentrations were similar at the start of the experiment in both control (not handled) and experimental (handled) groups of fish, becoming significantly greater at 2 and 4 hours and significantly lower at 30 hours in the handled fish compared with the controls. It is known that glucose is freely permeable by erythrocytes from mammals. However, in studies carried out with Antarctic Notothenidae fish, RODRIGUES et al. (1994) found 
out a variety of situations regarding blood glucose compartmentalization in this particular group of fish, glucose being distributed between plasma and erythrocytes in an uneven way. Furthermore, the meaning of the compartmentalization of blood glucose in fish in terms of erythrocyte metabolism is a fact still to be established, considering that most of the research published until now deals only with the levels of fish plasma glucose in different physiological conditions. MAURO and ISAACKS (1989), for instance, showed that lungfish (Lepidosiren paradoxa) erythrocytes unlike those in other species of fishes, oxidize endogenous glutamate at a higher rate than they oxidize glucose. On the other hand ROSA et al. (1989) carried out a research on the blood glucose partition and levels of glycolytic enzymes in erythrocytes of penguins disclosing the fact of the high levels of plasma glucose possessed by animals with nucleated erythrocytes. In the present paper a comparative study has been carried out on blood parameters and blood glucose partition from fish adapted to three different aquatic environments: Antarctic fish, fish from marine subtropical areas and fish from continental tropical rivers.

\section{Materials and Methods}

Specimens of Notothenia neglecta $(\mathrm{n}=25)$ were caught by nets near the Brazilian Antarctic Station, Admiralty Bay, King George Island, South Shetlands. Specimens of tropical fishes Pacu (Piaractus mesopotamicus $-\mathrm{n}=10$ ) and Curimbatá (Prochilodus scropha $-\mathrm{n}=7$ ) were from Faculdade de Engenharia de Alimentos, University of São Paulo, Pirassununga, São Paulo, Brazil. Subtropical marine fishes Rhinobatus percellens $(\mathrm{n}=6)$, Netuma barba $(\mathrm{n}=9)$, Menticirrhus litoralis $(\mathrm{n}=3)$, Mugil $\mathrm{spp}(\mathrm{n}=2)$ were caught at the Paranaguá Bay, State of Paraná, Brazil, Center of Sea Studies, Federal University of Paraná, Pontal do Sul, Paraná, Brazil. Once caught the fish were maintained and aclimated for three days in aquaria with running water. The specimens of Notothenia neglecta were maintained at $\mathrm{O}^{\circ} \mathrm{C}$ in aquaria with sea water. Blood samples were obtained by means of vein puncture of the caudal vein with vacuntainer tubing containing a mixture of heparin and sodium fluride. The handling of the fish was carefully conducted in order to minimize the stress to which they are usually subjected. Each fish was caught by a special hand net from the aquarium and immediately placed on an ice containing tray covered with a cloth and the puncture of the caudal vein carried out and collecting about $4-5 \mathrm{ml}$ of blood. The whole described operation up to the collecting of blood was performed in about 60 seconds. For the other species of fish from tropical and subtropical regions, the handling was carried out at room temperature. Aliquots of the blood were spun down at $1500 \mathrm{x} g$ to obtain plasma and the packed sediment of erythrocytes. Total blood was used for the determination of hematocrite (HT) and hemoglobin $\mathrm{Hb}$ ) which was assayed by the cyanomethemoglobin colorimetric method of VAN KAMPEN and ZIJLSTRA (1965). Glucose was assayed by both the glucose oxidase (TRINDER, 1969) and the otoluidine methods. For such purpose, aliquots of whole blood were deproteinized by means of tungstic acid or by the classical trichloroacetic acid.

\section{Results and Discussion}

Table 1 shows the results of the blood parameters studied - HT and $\mathrm{Hb}$ - and the blood glucose partition between plasma and erythrocytes. It can be seen that the percentile difference between the concentration of plasma glucose and that one of the total blood in all studied species led to the assumption that glucose is mainly compartmentalized at the plasma site. This might be an indication of an impaired glucose permeability experienced by the erythrocytes of those fishes.

Table 1. Hematrocrite (HT), haemoglobine $(\mathrm{Hb})$ and plasma and whole blood (WB) glucose values for fishes from different aquatic environments.

\begin{tabular}{l|l|l|l|l|l}
\hline \multirow{2}{*}{ Fishes } & \multicolumn{2}{l|}{ lycemia $(\mathrm{mMol} / \mathrm{L})$} & HT $(\%)$ & $\mathrm{P}(\%)$ & $\mathrm{Hb}(\mathrm{g} / \mathrm{dL})$ \\
\cline { 2 - 5 } & WB & & & \\
\hline Notothenia neglecta $(n=25)$ & $7.7 \pm 1.1$ & $11.4 \pm 1.8$ & $36.2 \pm 0.9$ & $32.7 \pm 10.3$ & $7.7 \pm 0.2$ \\
Netuma barba $(\mathrm{n}=9)$ & $2.5 \pm 0.3$ & $3.3 \pm 0.5$ & $24.5 \pm 1.2$ & $23.5 \pm 4.8$ & $5.7 \pm 0.4$ \\
Rhinobatos percellens $(\mathrm{n}=6)$ & $3.0 \pm 0.5$ & $3.8 \pm 0.6$ & $20.5 \pm 0.5$ & $21.2 \pm 5.1$ & $5.4 \pm 0.2$ \\
Menticirrhus litoralis $(\mathrm{n}=3)$ & $3.1 \pm 0.3$ & $4.2 \pm 0.2$ & $25.8 \pm 3.2$ & $25.0 \pm 9.4$ & $6.3 \pm 0.5$ \\
Mugil sp $(\mathrm{n}=2)$ & $10.0 \pm 3.9$ & $14.5 \pm 5.3$ & $36.2 \pm 0.8$ & $36,2 \pm 1,0$ & $9,2 \pm 0,3$ \\
Prochilodus scropha $(\mathrm{n}=7)$ & $3.0 \pm 0.7$ & $4.7 \pm 1.3$ & $34.2 \pm 2.3$ & $32.2 \pm 5.3$ & $12.9 \pm 1.1$ \\
Piaractus mesopotamicus $(\mathrm{n}=10)$ & $5.0 \pm 0.8$ & $7.3 \pm 1.1$ & $32.3 \pm 1.2$ & $31.6 \pm 2.1$ & $12.1 \pm 0.9$ \\
\hline
\end{tabular}

$P(\%)=$ Percentile differences between plasma and whole blood glucose concentration. Values expressed as mean \pm SE.

A comparative analysis regarding the blood glucose partition among the species of fish studied is shown in Fig. 1. In all cases the concentration of plasma glucose is higher than that one of the total blood in spite of the fact that the glycemic levels are quite different between 
the species studied. It is noteworthy however, the fact that Antarctic fish possess the highest glycemic values found (between 66 and 744 $\mathrm{mg} / \mathrm{dL}$ of plasma glucose and 39 and $398 \mathrm{mg} / \mathrm{dL}$ of whole blood glucose. When average values are calculated the following figures are reached: Notothenia neglecta (plasma $=209 \mathrm{mg} / \mathrm{dL}$; whole blood $=139 \mathrm{mg} / \mathrm{dL}$ ) when compared with fish species from other environments: Netuma barba $($ plasma $=59 \mathrm{mg} / \mathrm{dL}$; whole blood $=45$ $\mathrm{mg} / \mathrm{dL}$ ); Rhinobatos percellens (plasma $=68$ $\mathrm{mg} / \mathrm{dL}$; whole blood $=54 \mathrm{mg} / \mathrm{dL}) ;$ Menticirrhus litoralis (plasma $=76 \mathrm{mg} / \mathrm{dL}$; whole blood $=56$ $\mathrm{mg} / \mathrm{dL}) ;$ Mugil spp (plasma $=261 \mathrm{mg} / \mathrm{dL}$; whole blood $=180 \mathrm{mg} / \mathrm{dL}) ;$ Prochilodus scropha (plasma $=85 \mathrm{mg} / \mathrm{dL} ;$ whole blood $=54 \mathrm{mg} / \mathrm{dL})$; Piearactus mesopotamicus (plasma $=131 \mathrm{mg} / \mathrm{dL}$; whole blood $=91 \mathrm{mg} / \mathrm{dL}$ ).

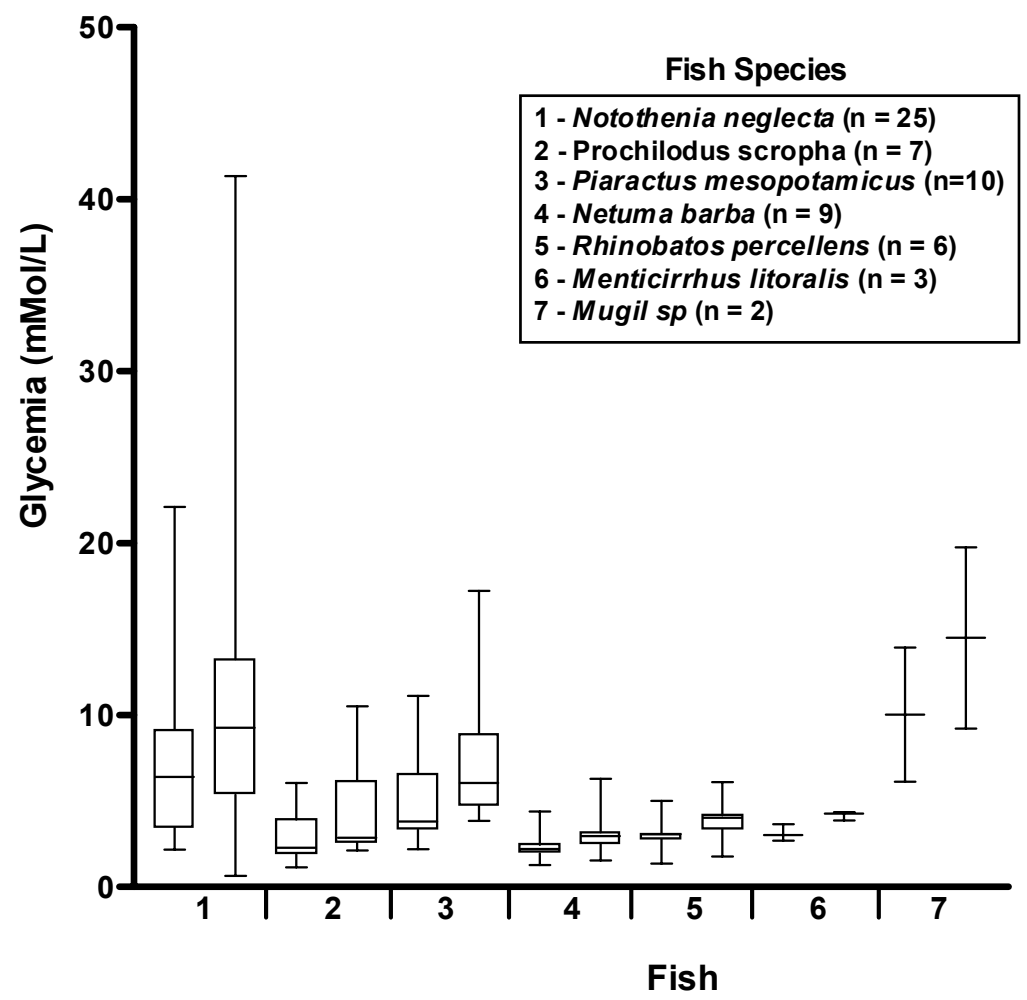

Fig.1. Plasma and whole blood glucose from Antarctic, marine subtropical and tropical continental water environments.

In regard to the present results it is worthwhile to consider that all the care has been taken in order to minimize the effect of the stress caused to the fish by the handling procedures, one important care being the quickness of each experimental step.

A study on the changes in carbohydrate metabolism in domesticated rainbow trout Onchorhynchus mykiss related to spermatogenesis was carried out by SOENGAS et al. (1993). Acording to these Authors, the increased glucose levels observed in testes during spermatogenesis are probably mainly due to an increased gluconeogenesis, the higher glucose levels being used not only in glycogen synthesis but also in generating reducing power. The effect of fish nutritional state in regard to the carbohydrate metabolism was also the subject of several papers. SHERIDAN and MOMMSEN (1991) showed that plasma glucose levels in Coho Salmon,
Onchorhynchus kisutch, are maintained during fasting and that fasting-induced hyperlipidemia is mediated by lipolytic enzyme activity, insulin, glucagon and glucagon-like peptide possibly interacting with these enzyme systems to coordinate the nutritional metabolism of fish.

\section{REFERENCES}

FLETCHER, D.J. Plasma glucose and plasma fatty acid levels of Limanda limanda (L.) in relation to season, stress, glucose loads and nutritional state. J. Fish Biol. 25:629-648, 1984.

KRIEGER-AZZOLINE， M.H.; DELATTRE， E.; CAROLSFELD, J.; CECCARELLI, P.; MENEZES, F.V. A time-course study of physiological indicators of handling stress in the tropical fish Piaractus mesopotamicus (Pacu). Brazilian J. Med. Biol. Res. 22:1019-1022, 1989. 
MAURO, N.A.; ISAACKS, R.E. Relative oxidation of glutamate and glucose by vertebrate erythrocytes. Comp. Biochem. Physiol. 94A(1):95-97, 1989.

OTTOLENGHI, C.; PUVIANI, A.C.; RICCI, D.; BRIGHENTI, L.; MORSIANI, E. The effect of high temperature on blood glucose level in two teleost fish (Ictalurus melas and Ictalurus punctatus). Сomp. Biochem. Physiol. 114A(2):229 -235, 1995.

PICKIRING, A.D.; POTTINGER, T.G.; CHRISTIE, P. Recovery of the brown trout, Salmo trutta L., from acute handling stress: a time-course study. J. Fish Biol. 20:229-244, 1982.

RODRIGUES, R.; MEDEIROS, A.; OCAMPOS, D.; ROSA, R.; BACILA, M. Blood Glucose Compartmentalization in Antarctic and Tropical Fish. IX Reunião Anual da Federação de Sociedades de Biologia Experimental, Caxambú, SP, Brazil. pp 300, 1994.

ROSA, R.; RODRIGUES, E.; BACILA, M. Blood glucose partition and levels of glycolitic enzymes in erythrocytes and somatic tissues of penguins. Comp. Biochem. Physiol. 92B(2):307-311, 1989.
SHERIDAN, M.A.; MOMMSEN, T.P. Effects of nutritional state on in vivo lipid na carbohydrate metabolism of Coho Salmon, Oncorhynchus kisutch. Gen. Comp. Endocr. 81:473-483, 1991.

SOENGAS, J.L.; SANMARTIN, B.; BARCIELA, P.; ALDEGUNDE, M.; ROZAS, G. Changes in carbohydrate metabolism in domesticated rainbow trout (Oncorhynchus mykiss) related to spermatogenesis. Comp. Biochem. Physiol. 105B(3/4):665-671, 1993.

TIIHONEN, K.; NIKINMAA, M. D-Glucose Permeability in River Lamprey (Lampetra fluviatilis) and Carp (Cyprinus carpio) Erythrocytes. Comp. Biochem. Physiol. 100A(3):581-584, 1991.

TRINDER, P. Determination of glucose in blood using glucose oxidase with na alternative oxygen acceptor. Ann. Clin. Biochem. 6:24-27, 1969.

VAN KAMPEN, E.J.; ZIJLSTRA, E.J. Determination of hemoglobin and its derivates. Adv. Clin. Chem. 8:141-187, 1965. 